Journal of the Bangladesh Association of Young Researchers (JBAYR): Volume 1, Number 2, June 2011, Page: 63-71, ISSN 1991-0746 (Print), ISSN 2220-119X (Online). DOI 10.3329/jbayr.v1i2.10032

Published by: BAtr

\title{
STUDY ON THE IRRIGATION WATER DISTRIBUTION SYSTEM DEVELOPED BY BARIND MULTIPURPOSE DEVELOPMENT AUTHORITY
}

\section{Md. Mosiur Rahman ${ }^{1}$, A.H.M. Kamal ${ }^{2}$, Abdullah Al Mamun ${ }^{3}$ and Dr. Md. Shafi Uddin Miah ${ }^{4}$}

1,2,3,4, Department of Civil Engineering, Rajshahi University of Engineering \& Technology (RUET)

E-mail: mosiur26ce@yahoo.com

\begin{abstract}
Irrigated agriculture has been playing a vital role for the growth in crop production in Bangladesh. Minor irrigation comprising of shallow tubewells (STWs), deep tubewells (DTWs), hand tubewells (HTWs) and low-lift pumps (LLPs) is a major irrigation system in the country. Poor performance of irrigation is an issue for the expansion of irrigated area. The present study was carried out to examine the conveyance efficiency and rate of irrigation water loss in DTW schemes in Bogra, Thakurgaon and Godagari zones of Barind Management Development Authority. There were various types of water distribution identified in these schemes with including Poly Venyl Chloride (PVC) buried pipe, cement concrete (CC) rectangular, Ferro trapezoidal, Ferro semicircular and rectangular earth drain. The average conveyance efficiency of PVC buried pipe for Bogra, Thakurgaon and Godagari zones ranged from $94.46 \%$ to $95.37 \%$ and rate of water loss ranged from $5.45 \%$ to $9.55 \%$ in three study zones. Average conveyance efficiency of CC rectangular for Bogra and Godagari zone ranged from $91.20 \%$ and rate of water loss from $6.58 \%$ to $9.93 \%$. Average conveyance efficiency of Ferro trapezoid for Bogra and Godagari zone ranged from $87.80 \%$ to $90.06 \%$ and rate of water loss ranged from $9.94 \%$ to $12.21 \%$. Average conveyance efficiency of Ferro semicircle for Bogra and Godagari zone ranged between $88.13 \%$ and $86.82 \%$ and rate of water loss between $11.59 \%$ and $11.68 \%$. Average conveyance efficiency and rate of water loss of rectangular earth drain Godagari zone was $58.66 \%$ and $42.29 \%$ respectively. About $80 \%$ farmers recommended buried pipe irrigation system and about $20 \%$ semi-circular channel. The study suggests that the improved water distribution system as developed by BMDA is sustainable to increase productivity of irrigation systems in Bangladesh.
\end{abstract}

Keywords: Irrigation scheme, Distribution system, Conveyance efficiency, Performance evaluation. 


\section{INTRODUCTION}

Ggrowth in crop production in the country primarily depends on the irrigation development. Due to absence of adequate surface water in the dry season, irrigation is heavily dependent on groundwater. With the increased in groundwater use and expansion of irrigated area inefficient water distribution and inadequate supply limit crop growth in irrigated fields. Thus, improvement of on-farm irrigation management practices and water distribution are now crucial for the growth in agricultural production. The optimum use of irrigation water should be an important strategy for increasing agricultural production in Bangladesh. Recently much attention has been given to improving the performance of existing irrigation systems instead of building new irrigation systems. The present study evaluates performance of irrigation water distribution system developed by BMDA in the northwest region of Bangladesh.

\section{DESCRIPTION OF THE STUDY AREA}

The study was carried out in three irrigation zones under BMDA in the northwest region of the country. In each zone two three schemes were selected. Descriptions of the schemes are as follows.

\section{BOGRA ZONE}

\section{a. RDA Farm scheme:}

This scheme is located at about $20 \mathrm{~km}$ south from Bogra town and $4 \mathrm{~km}$ from Sherpur upazila headquarters under Bogra district. DTW at RDA Farm was installed and the operation started in 1995. A submersible pump of capacity 56-60 I/s was used. Four types of open channel and underground buried pipe namely pre-cast Ferro-cement semi-circular, trapezoidal, cast in-situ CC rectangular with NCF and underground buried pipe (PVC pipe) of 508m, 633m, $241 \mathrm{~m}$ and $1510 \mathrm{~m}$ respectively introduced in 199596. The irrigation area covers about 30 ha.

\section{b. Atail scheme}

This scheme is located at about $20 \mathrm{~km}$ south of RDA, Bogra and $17 \mathrm{~km}$ from Sherpur upazila headquarters under Bogra district. The DTW at Atial was installed and started functioning 1980. A turbine pump of 56 $\mathrm{l} / \mathrm{s}$ capacity was coupled with a motor (3-phase induction motor). Open channels including pre-cast ferro-cement semi-circular, trapezoidal and CC rectangular channel of $400 \mathrm{~m}, 235 \mathrm{~m}$ and $355 \mathrm{~m}$ respectively were constructed in 2003-04. The area under irrigation is approximately 76 ha.

\section{c. Kahalu scheme}

This scheme is located at about $30 \mathrm{~km}$ north from RDA, Bogra and $13 \mathrm{~km}$ from Kotowali thana headquarters under Bogra district. DTW at Kahalu was installed and started in 1981. A turbine pump of $56 \mathrm{l} / \mathrm{s}$ capacity was coupled with a motor (3-phase induction motor). Open channel and underground buried pipe including pre-cast Ferro-cement semi-circular, trapezoidal, cast in-situ CC rectangular and underground buried pipe (PVC pipe) of $204 \mathrm{~m}, 218 \mathrm{~m}, 387 \mathrm{~m}$ and $473 \mathrm{~m}$ respectively were constructed in 1995-96. The area under irrigation is approximately 80 ha. 


\section{THAKURGAON ZONE}

\section{a. Jagannathpur Scheme}

It is located at about $5 \mathrm{~km}$ south-west from Thakurgaon town. The DTW at Jagannathpur Scheme was installed and started functioning in 2004. A submersible pump of $51 \mathrm{l} / \mathrm{s}$ capacity was coupled with a motor (3-phase induction motor). The scheme has $210 \mathrm{~m}$ long PVC buried pipe water distribution system which was constructed in 2005 . The area under irrigation is approximately 21 ha.

\section{b. Jhargaon Scheme}

It is located at about $8 \mathrm{~km}$ north-west from Thakurgaon town. The DTW at Jhargaon Scheme was installed and started functioning in 2004. A submersible pump of $51 \mathrm{l} / \mathrm{s}$ capacity was coupled with a motor (3-phase induction motor). The scheme has $235 \mathrm{~m}$ long PVC buried pipe water distribution system which was constructed in 2005. The area under irrigation is approximately 19 ha.

\section{c. Madhappur Scheme}

It is located at about $4 \mathrm{~km}$ north-east from Thakurgaon town. The DTW at Jhargaon Scheme was installed and started functioning in 2004. A submersible pump of $51 \mathrm{l} / \mathrm{s}$ capacity was coupled with a motor (3- phase induction motor). The scheme has $198 \mathrm{~m}$ long PVC buried pipe water distribution system which was constructed in 2005. The area under irrigation is approximately 18 ha.

\section{GODAGARI ZONE}

\section{a. Fazilpur Scheme}

It is located at about $2 \mathrm{~km}$ east from Godagari town. The DTW at Fazilpur Scheme was installed and started functioning in 2003. A submersible pump of $54 \mathrm{l} / \mathrm{s}$ capacity was coupled with a motor (3-phase induction motor). There are four types of open channel and underground including pre-cast ferrocement semi-circular, trapezoidal, cast in-situ CC rectangular, rectangular earth drain and underground buried pipe (PVC) of $410 \mathrm{~m}, 610 \mathrm{~m}, 720 \mathrm{~m}, 762 \mathrm{~m}$ and $760 \mathrm{~m}$ respectively which were constructed in 2004. The area under irrigation is approximately 22.7 ha.

\section{b. Sormongla Scheme}

It is located at about $5 \mathrm{~km}$ north-east from Godagari town. The DTW at Sormongla Scheme was installed and started functioning in 2003. A submersible pump of $54 \mathrm{l} / \mathrm{s}$ capacity was coupled with a motor (3phase induction motor). There are four types of open channel and underground pipe namely, pre-cast ferro-cement semi-circular, trapezoidal, cast in-situ CC rectangular, rectangular earth drain and underground buried pipe (PVC) of $381 \mathrm{~m}, 762 \mathrm{~m}, 810 \mathrm{~m}, 854 \mathrm{~m}$ and $915 \mathrm{~m}$ respectively which were constructed in 2004. The area under irrigation is approximately $37.4 \mathrm{ha}$.

\section{METHODOLOGY}

BMDA develops low cost channel for the improvement water distribution system since 1980 . The channels are better than traditional earthen channel especially in respect of efficiency and cost. Different types of channel with various materials have been tried in the farmer's field for improvement in water distribution system including better management of irrigation. The operational cost of 
traditional earthen channel has become a burden to the farmers unless the command area is large. The conveyance efficiency of traditional earthen channel is $50-55 \%$ and water loss rate $40-45 \%$ (BARI, 20007). In consideration with high water loss BMDA has developed six major distribution systems to reduce water loss:

(a) Lined open channel: Cast in-situ rectangular,

(b) Lined open channel; Cast in-situ Ferro-semicircular,

(c) Buried pipe irrigation (using PVC pipe),

(d) Lined open channel; Cast in-situ Ferro-trapezoidal, and

(f) Buried pipe irrigation in STW (using PVC/hose pipe).

\section{DETERMINATION OF CONVEYANCE EFFICIENCY}

Water conveyance efficiency (Ec) is the ratio in percent of the amount of water delivered by a channel or pipeline to the amount of water delivered to the conveyance system. Conveyance efficiency (Ec) was computed with the adoption of the following formula (James, 1988):

$E c=Q 0 / Q i * 100$

Where,

$\mathrm{Ec}=$ conveyance efficiency in percent

Qo = quantity of water delivered by a conveyance system (outlet)

$\mathrm{Qi}$ = quantity of water delivered to a conveyance system (inflow)

\section{a. Lined open channel}

There are several methods of measuring flow in open irrigation channels on the farm. They can be grouped into four categories:

(i) volumetric measurement,

(ii) velocity-area method,

(iii) measuring structures (orifices, weirs, flumes), and

(iv) Tracer methods (dilution).

In eight water distribution schemes volume of water (inflow and outflow) was measured by the velocityarea method. The rate of flow passing a point in an open channel was measured by multiplying the cross-sectional area of the flow section at right angles to the direction of flow by the average velocity of water. Discharge $=$ Area $*$ Velocity .

Discharge, $\mathrm{Q}=\mathrm{A} * \mathrm{~V}$

Where,

$$
\begin{aligned}
& Q=\text { discharge rate }(\mathrm{l} / \mathrm{s}) \\
& A=\text { area of cross-section of channel }\left(\mathrm{m}^{2}\right) \\
& V=\text { average velocity of flow }(\mathrm{m} / \mathrm{sec})
\end{aligned}
$$

The cross-sectional area was determined by direct measurements. The velocity was measured by float method. A straight section of channel about $20 \mathrm{~m}$ long with fairly uniform cross-section was selected. Several measurements of depth and width were made within the trial section to arrive at the average cross sectional area. Here inside diameter of pipe was considered to be $15.24 \mathrm{~cm}$, horizontal and vertical distance were $36 \mathrm{~cm}$ and $10.16 \mathrm{~cm}$ respectively and the Inlet discharge was $54(\mathrm{l} / \mathrm{s})$. To determine the 
velocity of surface water of the channel, the length of trail section was divided by the average time taken by the float cross it. Since the velocity of the float on the surface of the water will be greater than the average velocity of the stream, it was necessary to correct the measurement by multiplying by a constant factor (velocity correction factor) which is usually assumed to be 0.66 (James, 1988). To obtain the rate of flow, this average velocity (measured velocity * correction factor) was multiplied by the average cross-sectional area of the stream.

\section{b. Buried pipe}

The pump discharge from pipe was measured using Trajectory method. In this method the rate of flow is obtained by coordinate determination of any point of flow (Moniruzzaman, 1999). In operating condition the flow, at the outlet of pipe of the pump should be full flowing condition. The outlet of the pump may be horizontal or angular. For horizontal pipe, "L-scale" was used to measure the flow rate of the outlet pipe of pump in which small arm was 4 inch or 6 inch and long arm may be any value as required. The horizontal and vertical distances are called the " $\mathrm{X}$ " and " $\mathrm{Y}$ " coordinates, respectively. To get the values of " $X$ " and "Y" the long arm of L-scale was set horizontally above the pipe so as the small arm of the L-scale touch vertically just above the jet. The value of "Y" was constant as 4 inch. The inside diameter "D" of the pipe was also measured.

\section{DETERMINATION OF THE LOSSES OF IRRIGATION WATER}

The conveyance loss was measured using the inflow-outflow method, which involves measurement of the rate at which water flows in to a water course test section and the rate at which water flows out of it.

\section{a. Lined open channel}

Conveyance losses in the lined open channels were measured using velocity-area method. The reading was taken when the flow became steady. Readings were recorded simultaneously three times at 5 minutes interval. By measuring the section length under test the loss of water per $100 \mathrm{~m}$ was calculated by the following formula (Michael, 1986)

$Q_{1}=\left(Q_{i}-Q_{0}\right) / L^{*} 100$

Where,

$\mathrm{Q}_{1}=$ water loss rate in buried pipes $(\mathrm{l} / \mathrm{s} / 100 \mathrm{~m})$

$\mathrm{Q}_{0}=$ quantity of water delivered by a conveyance system (outlet) (I/s)

$\mathrm{Q}_{\mathrm{i}}=$ quantity of water delivered to a conveyance system (inflow) (I/s)

$\mathrm{L}=$ length of pipeline under test $(\mathrm{m})$

\section{b. Buried pipe}

To measure the water loss in buried pipes distribution, pump discharge was measured by trajectory method. This method was repeated three times to get an average discharge of the pump. The discharge at an outlet near the end of the main line was measured by velocity-area method. Measurements were taken simultaneously when the flow through the channel became steady. The water loss was calculated using the formula (3). 


\section{DATA ANALYSIS}

\section{A. EFFECT OF IMPROVED WATER DISTRIBUTION SYSTEM}

The changes in respect of command area, land for distribution system, irrigation cost, uniformity in distribution of irrigation water, time-span reaching the irrigation etc. are described in this section. Most of the data were collected through interview with the relevant farmers as well as managers and field observation. By using scheme map, the actual and potential command area, location of channel system and land use planning were also identified.

Table 1: Determination of conveyance efficiency and water loss of Thakurgaon zone

\begin{tabular}{|l|c|l|l|c|l|l|}
\hline $\begin{array}{l}\text { Name of } \\
\text { Scheme }\end{array}$ & $\begin{array}{l}\text { Length } \\
\text { of pipe L (m) }\end{array}$ & $\begin{array}{l}\text { Pump } \\
\text { discharge, } \\
\text { Qi (I/s) }\end{array}$ & $\begin{array}{l}\text { Outlet } \\
\text { discharge, } \\
\text { Qo (I/s) }\end{array}$ & $\begin{array}{l}\text { Efficiency Ec = } \\
\text { Qo/Qi *100 (\%) }\end{array}$ & $\begin{array}{l}\text { Water Loss } \\
\text { rate, QI = (Qi- } \\
\text { Qo)/L*100 }\end{array}$ & $\begin{array}{l}\text { Water } \\
\text { Loss (\%) }\end{array}$ \\
\hline Jaganna-Thpur & 210 & 51 & 47 & 92.17 & 1.90 & 7.84 \\
\hline Madhap-Pur & 235 & 51 & 46.89 & 92 & 1.75 & 8.06 \\
\hline Jhargaon & 198 & 51 & 47.67 & 93.47 & 1.69 & 6.53 \\
\hline
\end{tabular}

Table 2: Determination of average conveyance efficiency and water loss of Bogura zone

\begin{tabular}{|c|c|c|c|c|c|c|c|c|}
\hline \multirow[t]{2}{*}{$\begin{array}{l}\text { Type of } \\
\text { Distribution System }\end{array}$} & \multicolumn{3}{|c|}{$\begin{array}{l}\text { Conveyance Efficiency of } \\
\text { Scheme (\%) }\end{array}$} & \multicolumn{3}{|c|}{$\begin{array}{l}\text { Water Loss Rate of } \\
\text { Scheme (\%) }\end{array}$} & \multirow{2}{*}{$\begin{array}{l}\text { Average } \\
\text { Conveyance } \\
\text { Efficiency (\%) }\end{array}$} & \multirow{2}{*}{$\begin{array}{l}\text { Average } \\
\text { Rate of } \\
\text { Water } \\
\text { Loss (\%) }\end{array}$} \\
\hline & Atail & Kahalu & $\begin{array}{l}\text { RDA } \\
\text { Farm }\end{array}$ & Atail & Kahalu & $\begin{array}{l}\text { RDA } \\
\text { Farm }\end{array}$ & & \\
\hline Ferro semi-circular & 88.55 & 89.68 & 86.15 & 10.60 & 10.32 & 13.85 & 88.13 & 11.59 \\
\hline Ferro trapezoidal & 94.45 & 89.47 & 86.27 & 5.55 & 10.53 & 13.74 & 90.06 & 9.94 \\
\hline CC rectangular & 92.97 & 86.28 & 94.34 & 7.04 & 7.04 & 5.66 & 91.20 & 6.58 \\
\hline PVC Buried pipe & 95.38 & 95.53 & 95.20 & 6.12 & 7.42 & 4.80 & 95.37 & 6.11 \\
\hline
\end{tabular}

Table 3: Determination of average conveyance efficiency and water loss of Godagari zone

\begin{tabular}{|l|c|c|c|c|c|c|}
\hline \multirow{2}{*}{$\begin{array}{l}\text { Type of } \\
\text { Distribution System }\end{array}$} & \multicolumn{2}{|l|}{$\begin{array}{l}\text { Conveyance Efficiency } \\
\text { of Scheme (\%) }\end{array}$} & \multicolumn{2}{l|}{$\begin{array}{l}\text { Water Loss Rate of } \\
\text { Scheme (\%) }\end{array}$} & $\begin{array}{l}\text { Average } \\
\text { Conveyance } \\
\text { Efficiency (\%) }\end{array}$ & $\begin{array}{l}\text { Average Rate } \\
\text { of Water Loss } \\
\text { (\%) }\end{array}$ \\
\cline { 2 - 7 } & Fazilpur & Sormongla & Fazilpur & Sormongla \\
\hline PVC Buried pipe & 94.87 & 94.05 & 5.13 & 5.76 & 94.46 & 5.45 \\
\hline CC rectangular & 88.55 & 89.58 & 11.45 & 10.42 & 89.07 & 10.95 \\
\hline Ferro trapezoidal & 88.92 & 86.66 & 11.09 & 13.33 & 87.8 & 12.21 \\
\hline Ferro semicircular & 88.93 & 84.71 & 11.07 & 12.29 & 86.82 & 11.68 \\
\hline Rectangular Earth Drain & 59.61 & 57.71 & 40.33 & 42.29 & 58.66 & 41.31 \\
\hline
\end{tabular}

\section{B. EFFECT ON COMMAND AREA DEVELOPMENT}

The effects of improved water distribution system on command area development have been identified from field survey as shown in table 4. 
Table 4: Impact of improved water distribution system on command area

\begin{tabular}{|c|c|c|c|}
\hline Name of zone & $\begin{array}{l}\text { Name of } \\
\text { scheme }\end{array}$ & $\begin{array}{l}\text { Avg. command area before } \\
\text { improved distribution system } \\
\text { (ha) }\end{array}$ & $\begin{array}{l}\text { Avg. command area after improved } \\
\text { distribution system (ha) }\end{array}$ \\
\hline \multirow{3}{*}{ Thakurgaon } & Jagannathpur & 21 & 24.3 \\
\hline & Madhappur & 19 & 23.56 \\
\hline & Jhargaon & 18 & 21.1 \\
\hline \multirow{3}{*}{ Bogra } & Atail & 76 & 79.82 \\
\hline & Kahalu & 80 & 84.05 \\
\hline & RDA farm & 30 & 32.73 \\
\hline \multirow[b]{2}{*}{ Godagari } & Fazilpur & 22.7 & 25.23 \\
\hline & Sormongla & 37.4 & 40.26 \\
\hline
\end{tabular}

After the development of the improved water distribution system there has been a positive influence of the crop diversification project (CDP). It may be noted that with the rise in the command area there has been a concomitant increase in the number of water users as well. Improved water distribution system is reportedly the dominant factor behind this change.

\section{RESULT AND DISCUSSION}

\section{A. CONVEYANCE EFFICIENCY}

\section{i) Thakurgaon Zone}

Underground buried (PVC) pipe is the only type of water distribution system in the schemes in this zone. Table 1 show that the conveyance efficiency is $92.17 \%, 92 \%$ and $93.47 \%$ for Jagannathpur, Madhappur and Jhargaon schemes respectively and the average value is $92.55 \%$. It is important to note that Jhargaon scheme shows the highest conveyance efficiency (93.47\%) and Madhappur scheme has achieved the lowest performance (92\%). However all the systems have achieved significantly high conveyance efficiency in comparison with the national average $(40 \%)$.

\section{ii) Bogra Zone}

As shown in Table 2 the conveyance efficiency of PVC buried pipe, CC rectangular, Ferro trapezoidal and Ferro semi-circular system for Atail, Kahalu and RDA farm is $95.37 \%, 91.20 \%, 90.06 \%$ and $88.13 \%$ respectively. It is important to note that PVC buried pipe shows the highest conveyance efficiency $(95.37 \%)$ and Ferro semi-circular system shows the lowest performance $(88.13 \%)$.

\section{iii) Godagari Zone}

Table 3 shows that the conveyance efficiency of PVC buried pipe, CC rectangular, ferro trapezoidal, ferro semi-circular and rectangular earth drain system for Fazilpur and Sormongla is $94.46 \%, 89.1 \%, 87.8 \%$, $86.82 \%$ and $58.66 \%$ respectively. It is important to note that PVC buried pipe shows the highest conveyance efficiency (94.46\%) and rectangular earth drain system has achieved the lowest performance (58.66\%). 


\section{B. IRRIGATION WATER LOSS}

\section{a. Thakurgaon Zone}

The water losses from buried pipes of the study schemes as measured by inflow-outflow method was found be the highest (8.06\%) at Madhappur scheme and the lowest $(6.53 \%)$ at Jhargaon scheme.

\section{b. Bogra Zone}

The lowest water loss (6.11\%) was from PVC buried pipe and the highest (11.59\%) from Ferro semicircular.

\section{c. Godagari Zone}

The lowest water loss (5.45\%) was from PVC buried pipe and the highest (41.31\%) from rectangular earth drain.

\section{Benefit of BMDA developed improved water distribution system}

Main thrust of this study was to evaluate overall performance of BMDA developed different water distribution systems considering the technical as well as financial aspects. But technological considerations alone however are not enough to determine or justify the adoption of a particular method for agricultural improvements. It is also necessary to account the pattern of production by farmers and their production activities. As for the improved channel, all the farmers and water users expressed their complete satisfaction as it reduces the wastage of water and maintenance cost. Regarding all the farmers expression in relation to their preference for different types of channels innovated by the academy, about $80 \%$ expressed their views in support of the buried pipe irrigation system and about $20 \%$ for semi-circular shaped Ferro-cement channel. However, all the respondents were found to be silent with regard to the trapezoidal and rectangular channel system.

\section{CONCLUSIONS}

All the farmers and water user beneficiaries' views were positive in improved distribution system especially of buried pipe system. According to them, development of this lining technology is very appropriate in Bangladesh context and also in developing countries. More than $70 \%$ of the farmers and water user beneficiary opined that channel of every DTW schemes could be constructed buried pipe system. The conveyance efficiency of PVC buried pipe for Bogra, Thakurgaon and Godagari zone were $95.37 \%, 90.46 \%$ and $94.46 \%$ and rate of water loss were $6.11 \%, 9.55 \%$ and $5.45 \%$ respectively. BMDA developed water distribution systems are more effective, efficient and far better than the conventional system and developed water distribution systems at different locations in the country are running in good condition without any major constraint. This system could be widely adopted as a model in the field for increasing agricultural production in Bangladesh. Among all the water distribution systems, the PVC Buried pipe line system is the most suitable among all distribution systems.

\section{ACKNOWLEDGEMENTS}

The authors gratefully acknowledge the generous support of the head of Civil Engineering Department, Rajshahi University of Engineering \& Technology (RUET) during field survey. 


\section{REFERENCES:}

BADC (2006). Survey report on irrigation equipment and irrigated area in Boro/2005 season.

BARI (2007). Annual Report of Bangladesh Agricultural Research Institute.

BWB, (2008). Annual Report of Bangladesh Weather Bureau.

Bentum, R. and Smout, I. K (2006). Planning and Design of Buried Pipe Distribution System for surface irrigation-the I5th congress on ICID conference, the Hogue, the Netherlands.

Biswas (2005). An Investigation in to the Factor affecting the command area of different irrigation facilities in Bangladesh, p 25.

Khair, A. and Dutta, S. C (2000). Low cost canal lining for avoiding water losses to achieve efficient water distribution at farm level.

Gisselquist, D. (2001). Low Cost Concrete Pipe Irrigation System for DTWs, STWs and LLPs draft paper, Bangladesh.

Jenkins, D. (2001). Irrigation water distribution system for tubewells and low lift pumps in Bangladesh Dhaka, Bangladesh; United States Agency for International Development.

MacDonald (2002). Mott MacDonald International Ltd. main report: 1983-1992 IDA deep tubewell II project. Bangladesh.

Michael, A. M. (1986). Assessment of Research and Pilot Demonstration on Water Distribution Systems and Crop Water Requirement in Bangladesh.

Moniruzzaman, A. K. M. (1999). Effectiveness of Water Distribution Systems under Irrigation Technology Transfer Project.

Sanjit, K. D. and Tareq Ali Khan (2003). Determination of overall conveyance efficiency in a DTW Irrigation project: A case study in Bangladesh Agricultural University Farm, Mymensingh. p 47.

Sattar et al (2005). Assessment of research of deep tube well irrigation of Thakurgaon zone.

Hasan et al (2004). North Bangladesh tube wells project to evaluate the water distribution status in relation to maximizing the command area of the tube wells. 